\title{
FAKTOR-FAKTOR YANG MEMPENGARUHI KINERJA MANAJERIAL PERANGKAT DESA (STUDI PADA PERANGKAT DESA DI KABUPATEN SUMBAWA)
}

\section{FACTORS THAT AFFECT MANAGERIAL PERFORMANCE OF VILLAGE DEVICES (STUDY ON VILLAGE DEVICES IN SUMBAWA DISTRICT)}

\author{
Agus Wahyudi ${ }^{1}$, Sutjipto Ngumar ${ }^{2}$, Bambang Suryono ${ }^{3}$ \\ Sekolah Tinggi Ilmu Ekonomi Indonesia (STIESIA) Surabaya \\ 12aguswahyudistiesia@gmail.com, ${ }^{2}$ sutjiptongumar@stiesia.co.id, ${ }^{3}$ bambang_ppmb@yahoo.co.id
}

\begin{abstract}
Abstrak
Penelitian ini bertujuan untuk menguji pengaruh partisipasi penyusunan anggaran, akuntabilitas publik, pemanfataan aplikasi sistem keuangan desa, dan sistem pengendalian intern terhadap kinerja manajerial perangkat desa. Penelitian ini merupakan penelitian kuantitatif yang bersifat asosiatif. Penelitian ini dilakukan pada perangkat desa yang berada di wilayah Kabupaten Sumbawa dengan responden yakni kepala desa dan ketua badan permusyawaratan. Jumlah desa yang menjadi responden yakni berjumlah 75 desa sehingga total responden berjumlah 150 responden. Hasil penelitian menunjukkan bahwa sebesar 38,6\% variabel partisipasi penyusunan anggaran, akuntabilitas publik, pemanfataan aplikasi sistem keuangan desa, dan sistem pengendalian intern mampu menjelaskan variabel kinerja manajerial perangkat desa. Hasil statistik menunjukkan bahwa partisipasi penyusunan anggaran, akuntabilitas publik, dan pemanfaatan aplikasi sistem keuangan desa berpengaruh positif terhadap kinerja manajerial perangkat desa, sedangkan sistem pengendalian intern tidak berpengaruh terhadap kinerja manajerial perangkat desa, tidak berpengaruhnya sistem pengendalian intern terhadap kinerja manajerial dipengaruhi oleh beberapa hal diantaranya di mana perangkat desa hanyalah sebagai pelaksana yang bekerja sesuai dengan job desk-nya, perangkat desa hanya akan berfokus pada apa yang dikerjakan dan dibebankan bukan bertanggungjawab terhadap kebijakan pelaksanaan pengendalian intern, dan minimnya sumber daya manusia yang menjadi perangkat desa.
\end{abstract}

Kata Kunci : Kinerja Manajerial, Anggaran, Akuntabilitas Publik, Aplikasi Sistem Keuangan, Sistem Pengendalian

\begin{abstract}
This study aims to examine the effect of budgeting participation, public accountability, utilization of village financial system applications, and internal control systems on managerial performance of village officials. This research is an associative quantitative research. This research was conducted on village officials in the Sumbawa Regency area with respondents namely the village head and the head of village consultative agency. The number of villages that became respondents was 75 villages so that the total respondents were 150 respondents. The results showed that $38.6 \%$ of the budgeting participation variables, public accountability, utilization of village financial system applications, and internal control systems were able to explain the variable managerial performance of the village apparatus. The statistic results show that budgeting participation, public accountability, and utilization of village financial system applications have a positive effect on the managerial performance of village officials, while the internal control system does not affect the managerial performance of village officials the non-influence of the internal control system on managerial performance is influenced by several things including where the village apparatus is only the executor who works in accordance with his job desk, the village apparatus will only focus on what is done and charged, not responsible for the implementation of internal control policies, and the minimum human resources who become village officials.
\end{abstract}

Keywords : Managerial Performance, Budget, Public Accountability, Financial System Applications, Control Systems

PENDAHULUAN 
Undang-Undang Nomor 6 tahun 2014 tentang Desa telah melahirkan paradigma baru dalam pelaksanaan otonomi desa, yang meletakkan otonomi penuh, luas, dan bertanggung jawab pada masyarakat maupun pemerintah di atasnya. Otonomi desa telah memberikan kesempatan bagi pemerintah desa untuk menggali potensi alam dan potensi ekonomi yang dimiliki serta melakukan pemerataan pembangunan melalui program-program kegiatan dengan skala prioritas (Bhakti, et al, 2015). Dalam menyukseskan Undang-Undang ini pemerintah pusat semenjak tahun 2014 telah mengalokasikan dana desa untuk membiayai kebutuhan desa yang diperoleh dari Anggaran Pendapatan dan Belanja Negara (APBN).

Peningkatan pendapatan desa tersebut diharapkan dapat meningkatkan kinerja manajerial perangkat desa. Sebagai organisasi sektor publik, perangkat desa dituntut agar memiliki kinerja yang berorientasi pada kepentingan masyarakat dan mendorong pemerintah desa untuk senantiasa tanggap terhadap lingkungannya, dengan berupaya memberikan pelayanan terbaik secara transparansi, akuntabel dan berkualitas serta adanya pembagian tugas yang baik pada perangkat desa (Putra, 2013). Di mana kinerja manajerial merupakan hasil kerja organisasi dalam menjalankan kegiatan dan programnya yang bertujuan untuk melayani masyarakat (Ermawati, 2017). Untuk menentukan kinerja manajerial dari perangkat desa ada beberapa faktor yang mempengaruhinya diantaranya partisipasi penyusunan anggaran, akuntabilitas publik, pemanfaatan aplikasi sistem keuangan desa (siskeudes), dan sistem pengendalian intern.

Perangkat desa membutuhkan alat untuk mengkoordinasikan dan merencanakan sumber daya yang dimilikinya, di mana alat yang dapat membantu perencanaan, koordinasi, dan komunikasi antara pemerintah desa dan masyarakat ialah adanya suatu anggaran. Agar terbentuknya anggaran, diperlukan partisipasi dalam penyusunan anggaran tersebut dari semua elemen yang ada dalam desa tersebut. Partisipasi penyusunan anggaran mempunyai kaitan yang erat dengan kinerja manajerial perangkat desa, di mana kinerja pemangku kepentingan akan mempengaruhi proses penyusunan anggaran (Aulad, et al (2018). Partisipasi anggaran dapat dinilai dari tingkat seberapa jauh keterlibatan dan pengaruh perangkat desa dalam menentukan dan menyusun anggaran tersebut.

Fenomena yang dapat diamati dalam perkembangan partisipasi penyusunan anggaran yakni maraknya kasus-kasus penyimpangan dalam pengelolaan dana desa. Diantaranya yakni kasus dugaan penyimpangan dana desa pada Desa Mata Kecamatan Tarano Kabupaten Sumbawa. Kasus tersebut dimulai adanya laporan dari masyarakat setempat yakni dugaan sejumlah proyek yang tidak sesuai dengan spesifikasi dan ada juga pekerjaan yang belum tuntas serta penyimpangan penggunaan dana desa dari tahun 2016 dan 2017 yang belum juga selesai (pulausumbawanews.net). Hal ini memberikan kesadaran pentingnya partisipasi dalam penyusunan anggaran, yakni dengan terlibat langsung dalam proses penyusunan anggaran, perangkat desa dapat mengetahui apa yang akan dikerjakannya. Sehingga kinerja manajerial perangkat desa itu sendiri melalui terselenggaranya kegiatan yang diusungkan pada saat penyampaian aspirasi dalam penyusunan anggaran dapat berjalan sesuai dengan yang diaharapkan.

Akuntabilitas publik juga memiliki keterkaitan dalam kinerja manajerial pada perangkat desa. Putra (2013) menegaskan pentingnya akuntabilitas publik dalam peningkatan kinerja, karena dengan adanya akuntabilitas kepada masyarakat, masyarakat tidak hanya mengetahui anggaran tersebut tetapi juga mengetahui pelaksanaan kegiatan yang dianggarkan, sehingga perangkat desa berusaha dengan baik dalam melaksanakan seluruh perencanaan yang ada karena akan dinilai dan diawasi oleh masyarakat. Sehingga akuntabilitas akan terkait dengan pengawasan terutama dalam hal pencapaian hasil pada pelayanan publik dan menyampaikannya secara transparan kepada masyarakat dan diharapkan dari terciptanya akuntabilitas publik ini dapat meningkatkan kinerja manajerial perangkat desa (Benawan, et al. 2018).

Adanya akuntabilitas publik ini diharapkan perangkat desa dapat meningkatkan kinerja manajerial mereka, agar tidak terjadi penyimpangan dalam pengelolaan keuangan desa seperti yang terjadi pada desa-desa di Kabupaten Sumbawa. Pada tahun 2018, empat desa di Kabupaten Sumbawa tertunda dalam pencairan Dana Desa tahap II, hal ini dikarenakan adanya dugaan penyimpangan keuangan tahap sebelumnya, desa-desa tersebut ialah Desa Suka Mulia Kecamatan Labangka, Desa Sempe Kecamatan Moyo Hulu, Desa Tengah Kecamatan Labangka, dan Desa Lopok Beru Kecamatan Lopok. Penyelewengan anggaran di empat desa tersebut terindikasi 
sebagai tindak kesengajaan dari kepala desa masing-masing (www.kabarsumbawa.com). Sehingga diperlukan kesadaran dari aparat desa tentang pentingnya akuntabilitas terhadap publik dalam hal mencapai peningkatan kinerja manajerial perangkat desa. Tidak hanya hal negatif yang terjadi pada pemerintahan desa di wilayah Kabupaten Sumbawa. Di mana pada tahun 2017 Desa Uma Beringin Kecamatan Unter Iwes dan Desa Baru Tahan Kecamatan Moyo Utara diberikan penghargaan sebagai Desa Benderang Informasi Publik (DBIP) oleh Komisi Informasi Provinsi Nusa Tenggara Barat. Hal ini membuktikan bahwa pentingnya akuntabilitas sebagai bentuk pertanggungjawaban perangkat desa kepada publik.

Tidak hanya partisipasi penyusunan anggaran dan akuntabilitas publik yang terkait dengan kinerja manajerial perangkat desa, pemanfaatan aplikasi sistem keuangan desa juga berkaiatan dengan kinerja. Badan Pengawas Keuangan dan Pembangunan (BPKP) telah melakukan sinergi dengan pemerintah pusat maupun pemerintah daerah untuk mengembangkan aplikasi sistem keuangan desa serta melakukan pengawasan terhadap penggunaan aplikasi tersebut. Penerapan siskeudes ini tentunya disertai harapan agar dapat berjalan efektif sehingga mendukung pengelolaan keuangan desa yang lebih transparan, akuntabel, bebas dari penyalahgunaan dana serta pelaporan yang tepat waktu sehingga menunjang kinerja manajerial pemerintah desa (Saputri, 2018). Dengan adanya teknologi informasi maka pelayanan terhadap publik akan semakin meningkat dan menghasilkan informasi secara cepat dan akurat sehingga kinerja manajerial perangkat desa semakin meningkat.

Penggunaan aplikasi siskeudes ini sudah berjalan semenjak Bulan Mei 2017 di wilayah Kabupaten Sumbawa, namun tidak dipungkiri bahwa penggunaan aplikasi siskeudes di beberapa desa di Kabupaten Sumbawa belum maksimal. Hal ini disebabkan masih belum bagusnya sumber daya manusia seperti desa-desa di wilayah Kecamatan Batu Lanteh dari enam desa yang ada empat diantaranya merupakan desa sangat tertinggal (pulausumbawanews.net).

Agar berjalannya partisipasi penyusunan anggaran, akuntabilitas publik, dan pemanfaatan aplikasi sistem keuangan desa dalam mewujudkan peningkatan kinerja manajerial maka perlu dilakukan pengendalian intern untuk menjamin tercapainya tujuan pemerintah. Pengendalian intern digunakan sebagai alat ukur kegiatan dalam instansi pemerintah dapat dilaksanakan secara efektif dan menunjang kinerja perangkat desa (Saputri, 2018). Hal ini sejalan dengan tujuan dari sistem pengendalian intern sendiri yakni untuk memberikan keyakinan memadai tentang pencapaain tujuan pemerintah desa, keandalan pelaporan keuangan desa, dan kepatuhan terhadap perundangundangan yang berlaku.

Fenomena yang terjadi di Kabupaten Sumbawa yakni kinerja kepala desa di Kecamatan Moyo Utara diapresiasi oleh Bupati Sumbawa. Di mana Bupati menilai, selesainya APBDes secara tepat waktu mencerminkan adanya kekompakan dan kebersamaan antara kepala desa, aparatur desa dan semua unsur yang ada di desa tersebut. Selain itu penyelesaian APBDes juga tidak terlepas dari sistem pengendalian intern yang dilakukan oleh kepala desa sebagai pemegang kekuasaan pengelolaan keuangan desa dan sekretaris desa sebagai koordinator pelaksana teknis pengelolaan keuangan desa (pulausumbawanews.net).

Berbeda dengan penelitian-penelitian sebelumnya yang hanya melakukan penelitian pada pemerintah daerah antara lain Afrida (2013); Nasir dan Ranti (2013); Putra (2013); Putri (2013); Utama dan Abdul (2013); Saputra, et al (2014); Susanti (2014); Chintya (2015);Naipospos, et al (2015); Candrakusuma dan Bambang (2017); Damayanti (2017); Ermawati (2017); Heski, et al (2017); Sakti (2017); Aulad, et al (2018); Benawan, et al (2018); Hendra (2018); Siwi, et al (2018)), sedangkan penelitian ini mencoba melakukan penelitian pada pemerintah level bawah yakni perangkat desa. Penelitian ini juga melengkapi beberapa penelitian terdahulu di mana dalam penelitian ini menggunakan variabel partisipasi penyusunan anggaran (Utama dan Abdul (2013); Saputra, et al (2014); Bhakti, et al (2015); Medhayanti dan Ketut (2015); Naipospos, et al (2015); Aprilia (2017); Ermawati (2017); Handrika dan Made (2017); Heski, et al (2017); Sakti (2017); Aulad, et al (2018); Hendra (2018); Siwi, et al (2018)), akuntabilitas publik (Putra (2013); Saputra, et al (2014); Ibrahim (2015); Candrakusuma dan Bambang (2017); Damayanti (2017); Heski, et al (2017); Benawan, et al (2018);), pemanfaatan aplikasi sistem keuangan desa (Saputri, 2018), dan pengendalian intern (Afrida (2013); Nasir dan Ranti (2013); Putri (2013); Susanti (2014); Chintya 
(2015); Maharani, et al (2015); Candrakusuma dan Bambang (2017); Damayanti (2017); Mayarani, et al (2017); Taradipa (2017); Saputri (2018)).

Berangkat dari hal-hal tersebut sehingga penelitian ini bertujuan untuk menguji pengaruh partisipasi penyusunan anggaran, akuntabillitas publik, pemanfaatan aplikasi sistem keuangan desa, dan sistem pengendalian intern terhadap kinerja manajerial perangkat desa di wilayah Kabupaten Sumbawa.

\section{Kerangka Teoritis dan Pengembangan Hipotesis Stewardship Theory}

Stewardship Theory berangkat dari paradigma dalam pemikiran akuntansi manajemen yang banyak didasari oleh teori-teori psikologi dan sosiologi (Anton, 2010). Dalam pengelolaan Stewardship Theory, pengelolaan organisasi difokuskan pada keharmonisan diantara pemilik modal (principles) dengan pengelola modal (steward) dalam mencapai tujuan bersama. Stewardship theory menggambarkan manajer tidaklah termotivasi oleh kepentingan pribadi, melainkan kepentingan publik. Sehingga steward bekerja atas keinginan publik dengan mempertimbangkan kebutuhan prioritas.

Teori stewardship mengasumsikan hubungan yang kuat antara kesuksesan organisasi dengan kepuasan pemilik, steward akan melindungi dan memaksimalkan kekayaan organisasi dengan kinerja peusahaan, sehingga dengan demikian fungsi utilitas akan maksimal. Sehingga arti penting stewardsihp adalah bagaimana manajer meluruskan tujuan sesuai dengan tujuan bersama. Pemimpin yang dengan sukses dapat meningkatkan kinerja suatu organisasi akan mampu memuaskan kebutuhan dari organisasi tersebut, sebab sebagian besar pemangku kepentingan yang memiliki kepentingan yang telah dilayani dengan baik lewat peningkatan pelayanan yang diraih organisasi. Sehingga pemimpin akan termotivasi dalam memaksimalkan kinerjanya (Donalson dan James 1991).

Implikasi stewardship theory pada penelitian ini, dapat menjelaskan eksistensi perangkat desa sebagai lembaga yang dapat dipercaya untuk bertindak sesuai dengan kepentingan publik dengan melaksanakan tugas dan fungsinya dengan tepat, membuat pertanggungjawaban keuangan yang diamanahkan kepadanya, sehingga tujuan ekonomi pelayanan publik maupun kesejahteraan masyarakat dapat tercapai secara maksimal. Untuk melaksanakan tanggung jawab tersebut, maka dalam hal ini perangkat desa mengarahkan semua kemampuan dan keahliannya dalam meningkatkan partisipasi penyusunan anggaran, meningkatkan akuntabilitas publik, memanfaatkan aplikasi sistem keuangan desa dan melakukan pengendalian intern yang bertujuan untuk menunjang peningkatan kinerja manajerial perangkat desa.

\section{Pengaruh Partisipasi Penyusunan Anggaran terhadap Kinerja Manajerial Perangkat Desa}

Stewardship theory mengisyaratkan bahwa pengelolaan organisasi difokuskan pada keharmonisan antara masyarakat dan pemerintah dalam mencapai tujuan bersama. Terjalinnya keharmonisan ini dapat dilihat dari peran aktifnya semua unsur yang ada di desa tersebut dalam penyusunan anggaran. Anggaran pada sektor publik dibuat untuk membantu dalam menentukan tingkat kebutuhan masyarakat. Perangkat desa terlibat aktif dalam proses penganggaran, hal ini terlihat adanya kesempatan untuk ambil bagian dalam pengambilan keputusan melalui musyawarah terhadap target anggaran.

Partisipasi anggaran merupakan suatu hal untu menilai seberapa jauh keterlibatan dan pengaruh seseorang didalam menentukan dan menyusun anggaran secara tahunan. Partisipasi dalam penyusunan anggaran merupakan hal yang dapat meningkatkan kinerja yang pada akhirnya dapat meningkatkan efektivitas dari perangkat desa. Partisipasi yang baik diharapkan dapat meningkatkan kinerja manajerial, yaitu ketika suatu tujuan dirancang dan secara partisipatif disetujui, maka perangkat desa akan menginternalisasikan tujuan yang ditetapkan dan memiliki rasa tanggung jawab pribadi untuk mencapainya, karena mereka ikut terlibat dalam proses penyusunan anggaran tersebut.

Penelitian yang relevan dengan penelitian ini ialah Utama dan Abdul (2013); Bhakti, et al (2015); Naipospos, et al (2015); Heski, et al (2017); Sakti (2017), Aulad, et al (2018); Hendra (2018); serta Siwi, et al (2018), hasil penelitian mereka menunjukkan bahwa partisipasi 
penyusunan anggaran berpengaruh terhadap kinerja, hal ini berarti adanya anggaran partisipasi akan menghasilkan tukar menukar informasi yang efektif, melalui penyusunan anggaran secara partisipasi membuat perangkat desa akan memperoleh pemahaman yang lebih jelas akan pekerjaan mereka melalui anggaran tersebut. Dengan adanya anggaran partisipasi tersebut pemerintah desa didorong untuk lebih bertanggung jawab terhadap masing-masing tugas yang diembannya, sehingga perangkat desa akan meningkatkan kinerjanya, serta diharapkan agar mereka dapat mencapai sasaran atau target yang telah ditetapkan secara bersama dalam anggaran.

Berbeda dengan penelitian yang dilakukan oleh Candrakususma dan Bambang; (2017); Ermawati (2017); Handrika dan Made (2017), yang menunjukkan bahwa partisipasi penyusunan anggaran tidak berpengaruh terhadap kinerja. Hal ini dikarenakan tingkat keterlibatan perangkat desa rendah dalam proses penyusunan anggaran. Perangkat desa memang terlibat dalam proses penyusunan anggaran tetapi keterlibatan mereka tidak di imbangi dengan menyumbang ide-ide kreatif yang mereka miliki. Seharusnya dengan ikut terlibat dan bekerja dengan baik akan menghasilkan kinerja yang bagus.

Dengan adanya keterlibatan perangkat desa dalam penyusunan anggaran dapat meningkatkan kinerja manajerial perangkat desa. Sehingga berdasarkan penjelasan diatas, maka hipotesis yang diajukan sebagai berikut:

H1: Partisipasi Penyusunan Anggaran Berpengaruh Positif terhadap Kinerja Manajerial Perangkat Desa.

\section{Pengaruh Akuntabilitas Publik terhadap Kinerja Manajerial Perangkat Desa}

Eksistensi adanya stewardship theory ialah adanya pertanggungjawaban dari pemerintah desa kepada publik. Amanah tersebut dapat diimplementasikan melalui akuntabilitas publik. Pemerintah yang akuntabel merupakan pemerintah yang mampu mempertanggungjawabkan segala penggunaan sumber daya yang tersedia baik kepada publik. Perangkat desa dapat meningkatkan kinerja pemerintah itu sendiri dengan cara mampu memuaskan kebutuhan publik, sebab sebagian besar publik memiliki kepentingan yang telah dilayani dengan baik melalui peningkatan kemakmuran yang diraih perangkat desa. Oleh karena itu, steward yang pro pemerintah desa termotivasi untuk memaksimalkan kinerja perangkat desa, disamping dapat memberikan kepuasan kepada kepentingan publik.

Akuntabilitas publik merupakan prinsip yang menjamin bahwa tiap-tiap kegiatan yang dilakukan oleh perangkat desa yang diwakili oleh kepala desa dapat dipertanggungjawabkan kepada seluruh lapisan masyarakat secara terbuka (Sujarweni, 2015a;29). Putra (2013) berpendapat bahwa akuntabilitas merupakan prinsip pertanggungjawaban yang berarti bahwa proses dalam pengelolaan keuangan desa yang dimulai dari perencanaan, pelaksanaan dan penatausahaan harus benar-benar dilaporkan dan dipertanggungjawabkan kepada pemerintah diatasnya dan masyarakat. Hal ini menegaskan pentingnya akuntabilitas publik dalam peningkatan kinerja, karena dengan adanya akuntabilitas kepada masyarakat dan pemerintah diatasnya mereka tidak hanya mengetahui anggaran tersebut tetapi juga mengetahui pelaksanaan kegiatan yang dianggarkan sehingga pemerintah desa berusaha dengan baik dalam melaksanakan seluruh perencanaan yang ada karena akan dinilai dan diawasi oleh masyarakat.

Penelitian yang relevan dengan penelitian ini ialah Putra (2013); Saputra, et al (2014); Benawan, et al (2018) yang menunjukkan akuntabilitas publik berpengaruh terhadap kinerja. Hal ini terjadi karena kinerja perangkat desa diukur dan dinilai melalui laporan kinerja, untuk itu dalam peningkatan kinerja perangkat desa perlu adanya akuntabilitas publik. Adanya akuntabilitas publik mewajibkan perangkat desa yang diwakili oleh kepala desa harus memberikan pertanggungjawaban atas semua kegiatan yang dilaksanakannya sehingga kinerja perangkat desa dinilai baik oleh pihak internal maupun pihak eksternal, dengan demikian semakin tinggi tingkat akuntabilitas publik, maka peningkatan kinerja perangkat desa semakin naik.

Berbeda dengan penelitian Candarakusuma dan Bambang (2017) bahwa akuntabilitas publik tidak berpengaruh terhadap kinerja, hal ini menunjukkan bahwa aparatur daerah belum memahami secara keseluruhan prinsip pertanggungjawaban atas pelaksanaan atau perencanaan anggaran kepada publik. Masyarakat hanya mengetahui anggaran saja, tetapi tidak semua pelaksanaan kegiatan yang telah dianggarkan oleh pemerintah diketahui oleh masyarakat. 
Dengan adanya akuntabilitas publik yang diberikan oleh perangkat desa yang diwakili oleh kepala desa, maka dapat meningkatkan kinerja manajerial perangkat desa. Sehingga berdasarkan penjelasan diatas, maka hipotesis yang diajukan sebagai berikut:

H2: Akuntabilitas Publik Berpengaruh Positif terhadap Kinerja Manajerial Perangkat Desa.

\section{Pengaruh Pemanfaatan Aplikasi Sistem Keuangan Desa (SISKEUDES) terhadap Kinerja Manajerial Perangkat Desa}

Berdasarkan stewardship theory, masyarakat mengharapkan tanggung jawab bersama sesuai dengan kontribusi pemerintah desa. Hal ini berimplikasi pada tuntutan masyarakat agar pemerintah desa dapat mempertanggungjawabkan segala kegiatan yang dilakukan pada desa tersebut. Untuk menciptakan pertanggungjawaban tersebut, sejak 2015 perangkat desa telah memanfaatkan aplikasi sistem keuangan desa (siskeudes). Aplikasi ini digunakan oleh bendahara desa untuk mempermudahkannya dalam menatausahakan keuangan desa dan menghasilkan informai laporan atas penerimaan dan pengeluaran keuangan desa yang digunakan sebagai bahan pertanggungjawaban dan pengambilan keputusan.

Pemanfaatan teknologi informasi adalah perilaku/sikap menggunakan teknologi informasi untuk menyelesaikan tugas dan meningkatkan kinerja manajerial (Chintya, 2015). Sehingga diharapkan bendahara desa dapat memanfaatkan aplikasi siskeudes secara efektif. Saputri (2018) dalam tulisannya menyatakan bahwa Sebuah sistem akan efektif jika pengguna merasa puas dalam pengaplikasiannya, sistem mudah digunakan, biaya penerapan lebih kecil dibandingkan manfaat yang diperoleh organisasi dan data yang dihasilkan akan menunjang kinerja organisasi yang akurat, relevan, tepat waktu dan dapat dipertanggungjawabkan, sehingga organisasi mampu mencapai tujuannya dan mendukung pengambilan keputusan.

Susanti, (2014); Chintya (2015) dalam penelitiannya menjelaskan bahwa pemanfaatan teknlogi informasi berpengaruh terhadap kinerja pemerintah daerah. Di mana adanya pemanfaatan teknologi informasi yang tepat dan didukung oleh keahlian personil yang mengoperasikannya dapat meningkatkan kinerja instansi pemerintah. Adanya informasi yang tersedia dalam organisasi akan menjadi lebih efektif apabila dapat mendukung penggunaan informasi atau pengambilan keputusan. Manajer yang memiliki informasi umumnya mampu untuk membuat perencanaan yang lebih baik dan mencapai target yang telah ditetapkan, sehingga kinerja manajer akan meningkat. Dalam pemanfaatan aplikasi siskeudes, Saputri (2018) menjelaskan bahwa pemanfaatan siskeudes berpengaruh terhadap kinerja pemerintah desa, di mana adanya aplikasi akan membentuk laporan keuangan yang akurat, relevan, dan dapat dipertanggungjawabkan, sehingga kinerja pemerintah desa meningkat.

Berbeda dengan penelitian yang dilakukan oleh Nasir dan Ranti (2013); Damayanti (2017) menunjukkan bahwa pemanfaatan teknologi informasi tidak berpengaruh terhadap kinerja instansi pemerintah. Hal ini disebabkan pemanfaatan teknologi informasi oleh instansi pemerintah relatif kurang optimal dan belum menunjukan arah pembentukan e-Government yang baik.

Dengan adanya pemahaman tentang aplikasi sistem keuangan desa oleh bendahara desa, sehingga mempermudahkannya dalam bekerja maka dapat meningkatkan kinerja manajerial perangkat desa. Sehingga berdasarkan penjelasan diatas, maka hipotesis yang diajukan sebagai berikut:

H3: Pemanfaatan Aplikasi Sistem Keuangan Desa Berpengaruh Positif terhadap Kinerja Manajerial Perangkat Desa.

\section{Pengaruh Sistem Pengendalian Intern terhadap Kinerja Manajerial Perangkat Desa}

Stewardship theory didefinikasn sebagai situasi di mana kepala desa dan perangkat desa tidak mempunyai kepentingan pribadi tapi lebih mementingkan kepentingan masyarakatnya. Hal ini diartikan bahwa perangkat desa bekerja atas kepentingan publik. Sehingga untuk tercapainya hal ini maka dalam setiap kegiatan yang dilakukan oleh perangkat desa harus memiliki pengendalian intern dalam bekerja. Kepala desa dan perangkat desa sebagai steward (manajemen) tentunya harus mengarahkan semua kemampuannya untuk mengefektifkan pengendalian intern, hal ini bertujuan untuk memberi keyakinan bahwa kegiatan yang dilakukan dapat berjalan sesuai dengan apa yang telah ditetapkan, sehingga dengan terciptanya pengendalian intern yang baik maka akan lebih mudah dalam pencapaian kinerja yang lebih baik. 
Afrida (2013); Nasir dan Ranti (2013); Putri (2013); Susanti (2104); Chintya (2015); Maharani, et al (2015); Candrakusuma dan Bambang (2017); Taradipa (2017); serta Saputri (2018) menerangkan bahwa pengendalian intern berpengaruh terhadap kinerja. Adanya perangkat desa yang menerapkan sistem pengendalian intern yang baik akan mampu menghasilkan kegiatan yang baik pula. Sehingga adanya kegiatan yang baik tersebut membuat perangkat desa lebih mudah dalam pencapaian kinerja manajerial yang lebih baik.

Penelitian serupa juga dilakukan oleh Ibrahim (2015); Benawan, et al (2017) di mana penelitian mereka menunjukkan bahwa pengawasan berpengaruh terhadap kinerja. Jadi jika perangkat desa memiliki pengawasan yang baik, maka akan dapat memberikan rekomendasi terhadap pelaksanaan kegiatan-kegiatan organisasi yang akurat, lengkap, dan tepat waktu, maka output yang dikeluarkan akan semakin optimal sehingga dapat meningkatkan kinerja pemerintah desa.

Berbeda dengan penelitian yang dilakukan oleh Damayanti (2017), di mana pengendalian intern tidak berpengaruh terhadap kinerja. Sehingga adanya pengendalian intern tidak akan mempengaruhi tingkat kinerja yang dilakukan oleh perangkat desa. Mayarani, et al, (2017) juga menunjukkan indikator pengendalian internal yakni lingkungan pengendalian, aktivitas pengendalian, informasi dan komunikasi tidak berpengaruh terhadap kinerja karyawan.

Dengan adanya pengendalian intern yang dilakukan oleh kepala desa dan perangkat desa dalam setiap proses kegiatan dalam mengelola sumber daya yang ada maka akan mempermudahkan dalam meningkatkan kinerja manajerial perangkat desa. Sehingga hipotesis yang diajukan sebagai berikut:

H4: Sistem Pengendalian Intern Berpengaruh Positif terhadap Kinerja Manajerial Perangkat Desa.

\section{METODE}

\section{Jenis Penelitian dan Gambaran Populasi (Obyek) Penelitian}

Penelitian ini merupakan penelitian kuantitatif yang bersifat asosiatif, hal ini dikarenakan dalam penelitian ini yang bersifat menanyakan hubungan sebab akibat antar varibel independen yakni partisipasi penyusunan anggaran, akuntabilitas publik, pemanfaatan aplikasi sistem keuangan desa (siskeudes), dan sistem pengendalian intern dengan variabel dependen yakni kinerja manajerial perangkat desa yang. Populasi dalam penelitian ini ialah seluruh desa-desa yang berada di wilayah Kabupaten Sumbawa yang berjumlah 157 desa.

\section{Teknik Pengambilan Sampel dan Teknik Pengumpulan Data}

Teknik pengambilan sampel yang digunakan peneliti ialah menggunakan purposive sampling, dengan kriteria desa-desa yang berada di wilayah Kabupaten Sumbawa, desa-desa yang memperoleh transfer alokasi dana desa (ADD), dana desa (DD), bagian dari hasil pajak dan retribusi daerah (BHPRD) dan desa-desa yang mendapatkan bantuan keuangan kepada masyarakat yang disalurkan untuk pembentukan badan usaha milik desa (BUMDEs). Alasan peneliti menggunakan pertimbangan tersebut ialah karena dalam implementasi siskeudes diterangkan bahwa desa memiliki anggaran pendapatan dan belanja desa (APBDes) yang besarnya cukup relatif dan bervariasi sehingga menuntut pertanggungjawaban yang lebih tinggi dalam pengelolaannya. Sehingga sampel dalam penelitian ini berjumlah 75 desa. Teknik pengumpulan data dalam penelitian ini melalui penyebaran kuesioner. Kuesioner diisi oleh Kepala Desa dan Ketuan Badan Permusyawaratan Desa, sehingga responden dalam penelitian ini berjumlah 150 responden.

\section{Definisi Operasional Variabel dan Pengukurannya}

Di bawah ini disajikan tabel 1 tentang definisi operasional variabel dan pengukuran variabel yang digunakan oleh peneliti. 
Tabel 1. Definisi Operasional dan Pengukuran Variabel

\begin{tabular}{|c|c|c|c|}
\hline No. & $\begin{array}{c}\text { Variabe } \\
1\end{array}$ & $\begin{array}{c}\text { Definisi } \\
\text { Operasiona } \\
\text { I Variabel }\end{array}$ & Indikator \\
\hline \multirow[t]{7}{*}{1} & \multirow{7}{*}{$\begin{array}{l}\text { Kinerja } \\
\text { manajer } \\
\text { ial } \\
\text { perangk } \\
\text { at desa } \\
\text { (Aprilia, } \\
\text { 2017) }\end{array}$} & \multirow{7}{*}{$\begin{array}{l}\text { Kemampua } \\
\mathrm{n} \text { atau } \\
\text { prestasi } \\
\text { kerja yang } \\
\text { dicapai oleh } \\
\text { perangkat } \\
\text { desa untuk } \\
\text { melaksanak } \\
\text { an fungsi, } \\
\text { tugas, dan } \\
\text { kewajibann } \\
\text { ya dalam } \\
\text { menjalanka } \\
\mathrm{n} \\
\text { kegiatannya. }\end{array}$} & $\begin{array}{l}\text { a. Kualitas } \\
\text { pekerjaan }\end{array}$ \\
\hline & & & $\begin{array}{l}\text { b. Tanggung } \\
\text { jawab }\end{array}$ \\
\hline & & & $\begin{array}{l}\text { c. Pelaksanaan } \\
\text { tugas }\end{array}$ \\
\hline & & & $\begin{array}{l}\text { d. Memahami } \\
\text { peraturan }\end{array}$ \\
\hline & & & $\begin{array}{l}\text { e. Aktif } \\
\text { terhadap } \\
\text { aktivitas }\end{array}$ \\
\hline & & & $\begin{array}{l}\text { f. Teliti dalam } \\
\text { bekerja }\end{array}$ \\
\hline & & & $\begin{array}{l}\text { g. Keberhasilan } \\
\text { menjalankan } \\
\text { tugas }\end{array}$ \\
\hline \multirow[t]{4}{*}{2} & \multirow[t]{4}{*}{$\begin{array}{l}\text { Partisip } \\
\text { asi } \\
\text { penyusu } \\
\text { nan } \\
\text { anggara } \\
\text { n (Sakti, } \\
\text { 2017) }\end{array}$} & \multirow{4}{*}{$\begin{array}{l}\text { Keterlibatan } \\
\text { semua } \\
\text { elemen yang } \\
\text { ada di desa } \\
\text { tersebut } \\
\text { tanpa } \\
\text { terkecuali } \\
\text { seluruh } \\
\text { perangkat } \\
\text { desa dalam } \\
\text { menyusun } \\
\text { anggaran } \\
\text { serta } \\
\text { pelaksanaan } \\
\text { nya untuk } \\
\text { mencapai } \\
\text { target } \\
\text { anggaran } \\
\text { Perangkat } \\
\text { desa terlibat } \\
\text { dalam } \\
\text { proses } \\
\text { penganggara } \\
\text { n, di mana } \\
\text { mereka } \\
\text { diberi } \\
\text { kesempatan } \\
\text { untuk ambil } \\
\text { bagian } \\
\text { dalam } \\
\text { pengambilan } \\
\text { keputusan } \\
\text { melalui }\end{array}$} & $\begin{array}{l}\text { a. Keterlibatan } \\
\text { perangkat } \\
\text { desa } \\
\text { dalam } \\
\text { penyusunan } \\
\text { anggaran } \\
\end{array}$ \\
\hline & & & $\begin{array}{l}\text { b. Wewenang } \\
\text { Perangkat } \\
\text { desa dalam } \\
\text { penyusunan } \\
\text { anggaran } \\
\text { dan } \\
\text { berlakunya } \\
\text { anggaran }\end{array}$ \\
\hline & & & $\begin{array}{l}\text { c. Keterlibatan } \\
\text { perangkat } \\
\text { desa } \\
\text { dalam } \\
\text { pengawasan } \\
\text { proses } \\
\text { penyusunan } \\
\text { anggaran } \\
\end{array}$ \\
\hline & & & $\begin{array}{l}\text { d. Keterlibatan } \\
\text { perangkat } \\
\text { desa } \\
\text { dalam tujuan } \\
\text { pelaksanaan } \\
\text { anggaran } \\
\text { pada bidang } \\
\text { yang } \\
\text { dipimpin }\end{array}$ \\
\hline
\end{tabular}


negosiasi

terhadap

target

anggaran.

3 Akuntab Prinsip yang a. Akuntabilita

ilitas menjamin

S

publik bahwa tiap-

(Putra, tiap kegiatan

2013) yang

dilakukan

oleh

kejujuran

dan akuntabilitas

perangkat hukum

desa dapat

b. Akuntabilita

dipertanggu

S

ngjawabkan

proses

kepada

c. Akuntabilita

seluruh

$\mathrm{S}$

lapisan program

masyarakat

d. Akuntabilita

secara

kebijakan

terbuka

maupun

pemerintah

diatasnya

yang

diwakili

oleh kepala

desa.

\begin{tabular}{|c|c|c|}
\hline $\begin{array}{l}\text { Pemanf } \\
\text { aatan } \\
\text { aplikasi } \\
\text { sistem } \\
\text { keuanga } \\
\text { n desa } \\
\text { (Saputri, } \\
\text { 2018) }\end{array}$ & $\begin{array}{l}\text { Penggunaan } \\
\text { aplikasi } \\
\text { siskeudes } \\
\text { yang } \\
\text { diterapkan } \\
\text { dalam } \\
\text { pembuatan } \\
\text { laporan } \\
\text { keuangan } \\
\text { desa dengan } \\
\text { tujuan } \\
\text { memfasilitas } \\
\text { i aparatur } \\
\text { desa dalam } \\
\text { pembuatan } \\
\text { laporan } \\
\text { keuangan } \\
\text { desa dengan } \\
\text { mudah, } \\
\text { cepat dan } \\
\text { tepat serta } \\
\text { sesuai } \\
\text { dengan } \\
\text { peraturan } \\
\text { yang } \\
\text { berlaku. }\end{array}$ & $\begin{array}{c}\begin{array}{c}\text { a. Mudah } \\
\text { digunakan }\end{array} \\
\begin{array}{c}\text { b. Kepuasan } \\
\text { pengguna }\end{array} \\
\text { c. Data atau } \\
\text { laporan } \\
\text { yang } \\
\text { dihasilkan } \\
\text { cepat/tepat } \\
\text { waktu } \\
\text { d.Dilengkapi } \\
\text { keamanan } \\
\text { e. Ekonomis }\end{array}$ \\
\hline
\end{tabular}




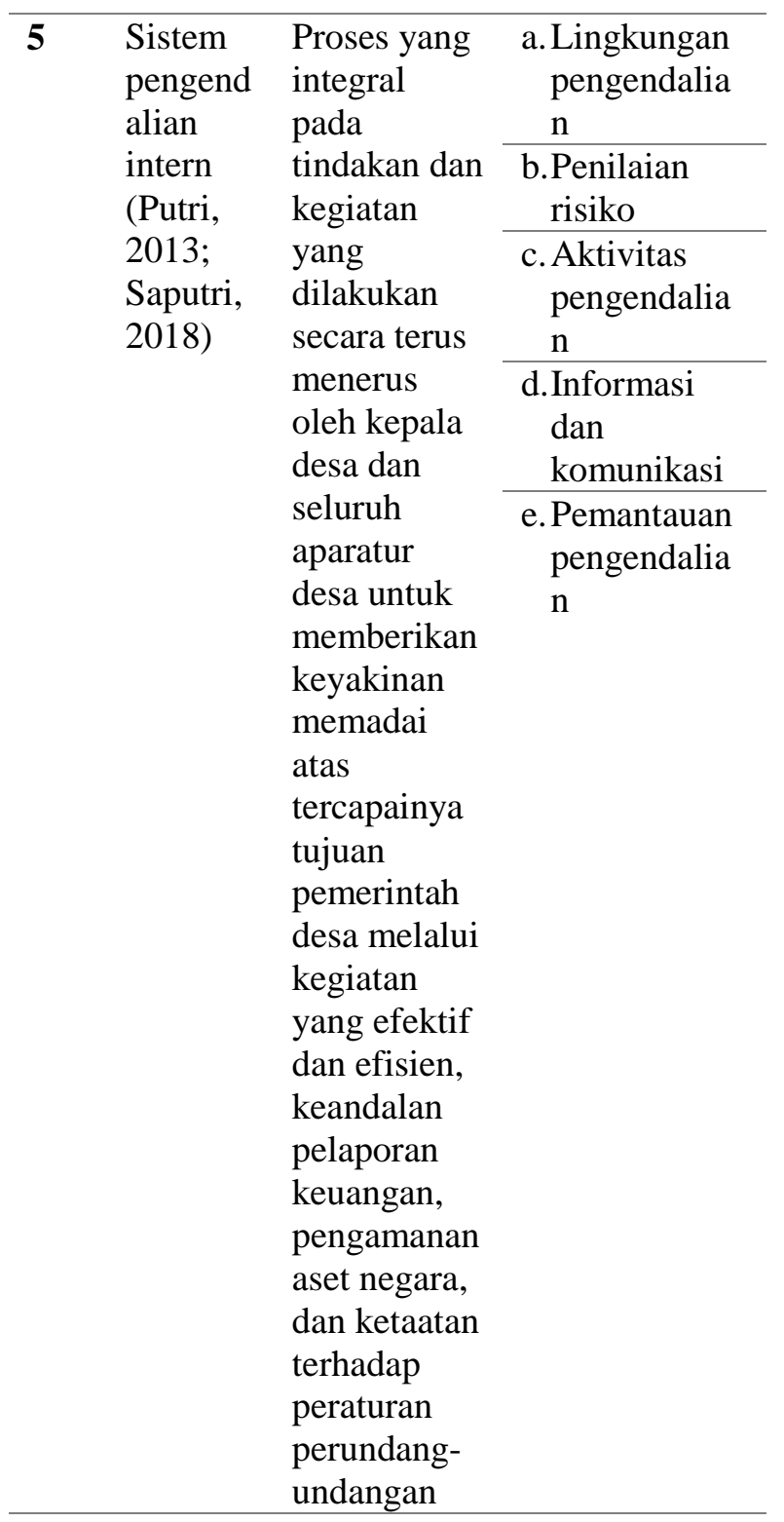

Sumber: Data diolah oleh peneliti (2019)

\section{Teknik Analisis Data}

Teknik analisis data dalam penelitian ini meliputi beberapa tahapan yakni (1) Uji kualitas data yang terdiri atas uji validitas dengan ketentuan jika nilai $r$ hitung lebih dari $r$ tabel $\left(\mathrm{r}_{\text {hitung }}>\right.$ $\mathrm{r}_{\text {tabel }}$ ) maka butir-butir pernyataan tersebut valid dan uji reliabilitas dengan ketentuan dikatakan reliabel jika nilai cronbach alpha lebih dari 0,60 (Ghozali, 2016:47-48). (2) Uji asumsi klasik meliputi uji normalitas dengan menggunakan uji Kolmogrov-Smirnov pada tingkat signifikan 5\%, uji multikolonieritas dengan cara melihat angka collinearity Statistics yang ditunjukan oleh Nilai Variance inflation Factor (VIF). Jika angka VIF > 10, maka variabel bebas memiliki masalah multikolinearitas dan nilai tolerance pada output penilaian multikolinearitas yang tidak menunjukan nilai lebih besar dari 0,1 akan memberikan kenyataan bahwa tidak terjadi masalah multikolinearitas, dan uji heteroskedastisitas menggunakan uji rank spearman dengan kriteria Jika nilai signifikansi variabel independen > 0,05 maka tidak terjadi heteroskedastisitas. (3) Uji Koefisien determinasi $\left(\mathrm{R}^{2}\right)$ pada dasarnya mengukur seberapa jauh kemampuan model dalam menerangkan variasi variabel dependen. (4) Uji kesesuaian model yang digunakan apakah model yang digunakan dalam penelitian ini telah sesuai atau tidak yakni jika nilai $\mathrm{F}$ lebih besar daripada 4 dan nilai signifikan kurang dari 5\% (<5\%) maka semua variabel independen secara serentak dan signifikan mempengaruhi variabel dependen. (5) Uji statistika parameter individual atau uji t 
dengan ketentuan apabila nilai statistik t hasil perhitungan lebih tinggi dibandingkan nilai t-tabel $\left(\mathrm{T}_{\text {hitung }}>\mathrm{T}_{\text {tabel }}\right)$, maka variabel independen secara individual mempengaruhi variabel dependen. (Ghozali, 2016;97). (6) Analisi regresi linier berganda, di mana dalam penelitian ini memiliki persamaan linier berganda seperti berikut ini:

Keterangan:

$$
\mathrm{KPD}=\mathrm{a}+\mathrm{b}_{1} \mathrm{PPA}+\mathrm{b}_{2} \mathrm{AKP}+\mathrm{b}_{3} \mathrm{PAS}+\mathrm{b} 4 \mathrm{SPI}+\mathrm{e} \ldots . .
$$

$\begin{array}{ll}\text { KMP } & =\text { Kinerja Perangkat Desa } \\ \mathrm{a} & =\text { Konstanta } \\ \mathrm{b}_{1}-\mathrm{b}_{4} & =\text { Koefisien Regresi } \\ \text { PPA } & =\text { Partisipasi Penyusunan Anggaran } \\ \text { AKP } & =\text { Akuntabilitas Publik } \\ \text { PAS } & =\text { Pemanfaatan Aplikasi Siskeudes } \\ \text { SPI } & =\text { Sistem Pengendalian Intern } \\ \mathrm{e} & =\text { Error/Variabel Pengganggu }\end{array}$

\section{HASIL DAN PEMBAHASAN}

\section{Gambaran Objek Penelitian dan Karakteristik Responden}

Kabupaten Sumbawa merupakan salah satu dari kabupaten/kota yang berada di wilayah Provinsi Nusa Tenggara Barat. Jarak tempuh dari ibu kota kabupaten ke kota-kota kecamatan ratarata $45 \mathrm{Km}$. Kecamatan terjauh yaitu kecamatan tarano dengan jarak tempuh $103 \mathrm{~km}$. Kabupaten Sumbawa terbagi atas 24 kecamatan, 157 desa, 8 kelurahan, dan 657 dusun/lingkungan. Dalam menjalankan pemerintahan sampai level desa, seorang kepala desa/lurah dibantu oleh aparat desa/kelurahan yang berada dibawah naungannya. Kepala desa/lurah di Kabupaten Sumbawa berjumlah 165 orang, aparat desa/kelurahan berjumlah 1.913 orang, badan permusyawaratan desa 1.146 orang, ketua rukun warga (RW) 1.159 orang, dan ketua rukun tetangga (RT) 2.940 orang. Jumlah penduduk di Kabupaten Sumbawa ialah 449.680 orang (www.sumbawakab.bps.go.id, 2018).

Penelitian ini dilakukan melalui penyebaran kuesioner kepada 150 responden, kuesioner semuanya kembali dan dapat di olah. Berdasarkan hasil kuesioner sebanyak 146 responden adalah laki-laki atau berkisar $97,3 \%$ dan sisanya sebanyak 4 responden atau 2,7\% adalah perempuan. Umur responden terbanyak berada pada interval 41-50 tahun yakni sebanyak 76 orang atau $50,7 \%$, kedua disusul pada interval 51-60 tahun yakni 43 orang atau $28,7 \%$, ketiga disusul pada interval 31-40 tahun yakni 27 orang atau 18\%, keempat pada interval $>60$ tahun yakni 3 orang atau 2\%, dan terakhir berada pada interval 20-30 tahun yang berjumlah 1 orang atau $0,7 \%$. Sesuai dengan amanat Undang-Undang Nomor 6 Tahun 2014 tentang Desa, bahwa umur kepala desa minimal 25 tahun dan ketua badan permusyawaratan desa minimal 20 tahun.

Berdasarkan tingkat pendidikan dari responden pada urutan pertama ialah SMA yakni berjumlah 106 orang atau 70,7\%, kedua S-1 berjumlah 33 orang atau 22\%, ketiga SMP dan D-3 berjumlah masing-masing 4 orang atau 2,7\%, dan keempat D-2 berjumlah 3 orang atau 2\%. Hal ini telah sesuai dengan amanat Undang-Undang Nomor 6 Tahun 2014 tahun 2017 bahwa minimal tingkat pendidikan kepala desa dan ketua badan permusyawaratan desa ialah Sekolah Menengah Pertama (SMP). Berdasarkan masa kerja dari responden pada urutan pertama ialah kurang dari 5 tahun yakni berjumlah 66 orang atau $44 \%$, urutan kedua yakni dengan masa kerja lebih dari 10 tahun yakni berjumlah 59 orang atau 39,3\%, dan terakhir 5-10 tahun berjumlah 25 orang atau $16,7 \%$. Hal ini membawa arti penting bahwa diperlukan pemahaman dan tindakan yang lebih baik lagi dalam meningkatkan kinerja manajerial perangkat desa karena masa kerja didominasikan oleh responden kurang dari 5 tahun.

\section{Uji Kualitas Data}

Berdasarkan hasil olahan data seluruh pernyataan dikatakan valid. Hal ini dikarenakan $r$ tabel lebih besar dari $r$ hitung. Dengan demikian variabel kinerja manajerial perangkat desa, partisipasi 
penyusunan anggaran, akuntabilitas publik, pemanfataan aplikasi sistem keuangan desa, dan sistem pengendalian intern memiliki nilai $r$ hitun lebih dari 0,162 sehingga dinyatakan item pernyataan yang digunakan valid. Kemudian hasil uji reliabitas menunjukkan bahwa seluruh variabel reliabel karena nilai cronbach alpha lebih dari 0,60.

\section{Uji Asumsi Klasik}

Pengujian ini meliputi (1) uji normalitas di mana nilai Asymp. Sig. (2-tailed) yakni berjumlah 0,200, hal ini menunjukkan bahwa data residual terdistribusi normal dikarenakan nilai Asymp. Sig. (2-tailed) lebih dari 0,05 , (2) uji multikolonieritas di mana disimpulkan variabel bebas dalam penelitian ini bebas dalam masalah multikolonieritas, hal ini dikarenakan nilai VIF kurang dari 10 dan nilai tolerance lebih dari 0,1 dan (3) uji heteroskedastisitas di mana dapat disimpulkan bahwa variabel partisipasi penyusunan anggaran, akuntabilitas publik, pemanfaatan aplikasi sistem keuangan desa, dan sistem pengendalian intern bebas dari masalah heteroskedastisitas. Hal ini dikarenakan nilai signifikansi keempat variabel tersebut lebih dari 0,05.

\section{Uji Koefisiensi Determinasi Regresi $\left(\mathbf{R}^{2}\right)$}

Berdasarkan nilai Adjustes $R^{2}$ yakni sebesar 0,386, hal ini berarti sebanyak 38,6\% variabel kinerja manajerial perangkat desa mampu dijelaskan oleh variabel partisipasi penyusunan anggaran, akuntabilitas publik, pemanfaatan aplikasi sistem keuangan desa, dan sistem pengendalian intern. Sedangkan sisanya 61,4\% (100\%-38,6\%) dijelaskan oleh faktor-faktor lain yang tidak diikutkan dalam penelian ini.

\section{Uji Kelayakan Model}

Dalam pengujian kesesuaian model ini peneliti melihatnya dari uji ANOVA yakni pada nilai F dan tingkat signifikansi. Di mana hasilnya menunjukkan bahwa nilai $F$ sebesar 24,646, yang mana dapat disimpulkan bahwa variabel partisipasi penyusunan anggaran, akuntabilitas publik, pemanfataan aplikasi sistem keuangan desa, dan sistem pengendalian intern secara serentak mempunyai pengaruh terhadap variabel kinerja manajerial perangkat desa. Hal ini dikarenakan nilai $F$ lebih besar dari 4. Nilai signifikansi juga menunjukkan angka kurang dari 0,05 yakni 0,000 sehingga penelitian ini dapat dilanjutkan.

\subsection{Uji statistika parameter individual atau uji $t$}

Hasil uji statistika parameter individual (uji statistika t) dapat dilihat pada tabel 2.

Tabel 2. Uji Statistika Paramaeter Individual (Uji Statistka t)

\begin{tabular}{lccc}
\hline Variabel & ai t & Nil & $\begin{array}{c}\text { Nilai } \\
\text { Signifikansi }\end{array}$ \\
\hline Partisipasi penyusunan anggaran & 80 & 3,0 & 0,002 \\
Akuntabilitas publik & & 2,3 & 0,021 \\
Pemanfaatan aplikasi sistem keuangan desa & 32 & 2,1 & 0,034 \\
Sistem pengendalian intern & 44 & & 0,252 \\
\hline
\end{tabular}

Sumber: Data diolah oleh peneliti (2019)

Berdasarkan tabel 2 dapat dilihat untuk variabel partisipasi penyusunan anggaran nilai $\mathrm{t}=$ 3,080 dan nilai signifikansi 0,002 . Hal ini bermakna bahwa partisipasi penyusunan anggaran berpengaruh positif terhadap kinerja manajerial perangkat desa, dikarenakaN nilai t hitung lebih besar dari $t$ tabel $\left(t_{\text {hitung }}=3,080>t_{\text {tabel }} 1,9765\right)$ dan nilai signifikansi kurang dari 0,05 . Sehingga hipotesis pertama diterima.

Variabel akuntabilitas publik menunjukkan hasil yang signikan yakni 0,021 dengan nilai $t$ hitung $=2,332$. Hal ini berarti akuntabilitas publik berpengaruh positif terhadap kinerja manajerial 
perangkat desa, dikarenakan nilai $t$ hitung lebih besar dari $t$ tabel $\left(t_{\text {hitung }}=2,332>t_{\text {tabel }} 1,9765\right)$ dan nilai signifikansi kurang dari 0,05 . Sehingga hipotesis kedua diterima.

Dari hasil pengujian yang terdapat pada tabel 2 untuk variabel pemanfataan aplikasi sistem keuangan desa menunjukkan nilai $t$ hitung $=2,144$ dengan tingkat signifikansi 0,034 . Hal ini menunjukkan bahwa pemanfaatan aplikasi sistem keuangan desa berpengaruh positif terhadap kinerja manajerial perangkat desa. Hal ini dikarenakan nilai $\mathrm{t}$ hitung lebih besar dari $\mathrm{t}$ tabel $\left(\mathrm{t}_{\text {hitung }}=\right.$ $2,144>t_{\text {tabel }} 1$ 1,9765) dan nilai signifikansi kurang dari 0,05. Sehingga hipotesis ketiga diterima.

Hasil pengujian yang tertera pada tabel 2 untuk variabel sistem pengendalian intern menunjukan nilai $\mathrm{t}=1,151$ dengan nilai signifikansi 0,252 . Hal ini berarti sistem pengendalian intern tidak berpengaruh terhadap kinerja manajerial perangkat desa, dikarenakan nilai t hitung kurang dari $\mathrm{t}$ tabel $\left(\mathrm{t}_{\text {hitung }}=1,151<\mathrm{t}_{\text {tabel }} 1,9765\right)$ dan nilai signifikansi lebih dari 0,05 . Sehingga hipotesis ditolak.

\section{Analisis Regresi Linier Berganda}

Hasil pengujian statistika parameter individual menghasilkan model regresi sebagai berikut:

$$
\mathrm{KPD}=0,440+0,327 \mathrm{PPA}+0,238 \mathrm{AKP}+0,156 \mathrm{PAS}+0,144 \mathrm{SPI}+\mathrm{e}
$$

di mana:

$\begin{array}{ll}\text { KPD } & =\text { Kinerja Manajerial Perangkat Desa } \\ \text { PPA } & =\text { Partisipasi Penyusunan Anggaran } \\ \text { AKP } & =\text { Akuntabilitas Publik } \\ \text { PAS } & =\text { Pemanfataan Aplikasi Sistem Keuangan Desa } \\ \text { SPI } & =\text { Sistem Pengendalian Intern } \\ \mathrm{e} & =\text { error/gangguan }\end{array}$

Berdasarkan persamaan di atas, dapat dilihat bahwa koefisien variabel partisipasi penyusunan anggaran bernilai positif sebesar 0,327 , koefisien variabel akuntabilitas publik bernilai positif sebesar 0,238 , koefisien variabel pemanfataan aplikasi sistem keuangan desa bernilai positif sebesar 0,156, dan koefisien variabel sistem pengendalian intern bernilai positif sebesar 0,144 yang berarti kinerja manajerial perangkat desa meningkat dengan adanya partisipasi penyusunan anggaran, akuntabilitas publik, dan pemanfataan aplikasi sistem keuangan desa.

\section{Pembahasan \\ Pengaruh Partisipasi Penyusunan Anggaran terhadap Kinerja Manajerial Perangkat Desa}

Hasil pengujian hipotesis menunjukkan bahwa partisipasi penyusunan anggaran berpengaruh positif terhadap kinerja manajerial perangkat desa. Hal ini membuktikan eksistensi stewardship theory yang menginsyaratkan bahwa pengelolaan keuangan desa akan terjalin secara harmonis ketika perangkat desa berpartisipasi dalam penyusunan anggaran. Ketika perangkat desa terlibat aktif dalam proses penganggaran, hal ini terlihat adanya kemampuan untuk ambil bagian dalam pengambilan keputusan melalui musyawarah desa dalam target anggaran desa. Perangkat desa berpartisipasi secara aktif dan memberikan usulan dalam penyusunan anggaran, sehingga dengan mudah untuk mengawasi program/kegiatan yang dilakukan.

Pengelolaan keuangan desa yang baik diharapkan dapat mengedepankan asas-asas pengelolaan keuangan desa seperti yang diamanatkan dalam Undang-Undang Nomor 6 Tahun 2014 tentang Desa dan turunannya bahwa pengelolaan keuangan desa dilakukan secara partisipasi. Hal ini dilakukan agar dapat menilai sejauh mana keterlibatan dan pengaruh dari perangkat desa dalam menentukan dan menyusun anggaran desa. Sehingga dengan adanya partisipasi dalam penyusunan anggaran yang dilakukan oleh perangkat desa dapat meningkatkan kinerja manajerial perangkat desa. Hal ini dikarenakan tujuan yang telah dirancang dan secara partisipatif disetujui, maka perangkat desa akan menginternalisasikan tujuan yang telah ditetapkan tesebut dan perangkat desa akan merasa memiliki rasa tanggung jawab untuk mencapainya, karena mereka terlibat dalam proses penyusunan anggaran desa. 
Hasil penelitian ini sejalan dengan penelitian yang dilakukan oleh Utama dan Abdul (2013); Bhakti, et al (2015); Naipospos, et al (2015); Heski, et al (2017); Sakti (2017), Aulad, et al (2018); Hendra (2018); serta Siwi , et al (2018), yang menunjukkan partisipasi penyusunan anggaran berpengaruh terhadap kinerja manajerial perangkat desa. Hal ini membawa kesadaran bahwa partisipasi dalam penyusunan anggaran akan membawa dampak pada tukar menukar informasi yang efektif. Adanya keterlibatan perangkat desa, akan membuat mereka memperoleh gambaran pemahaman yang lebih jelas tentang pekerjaan yang akan mereka kerjakan melalui anggaran desa yang telah ditetapkan dari hasil partisipasi penyusunan anggaran tersebut. Sehingga perangkat desa termotivasi untuk bertanggung jawab atas tugas yang diamanahkan kepadanya yang akhirnya dapat meningkatkan kinerja manajerial perangkat desa.

\section{Pengaruh Akuntabilitas Publik terhadap Kinerja Manajerial Perangkat Desa}

Hasil penelitian menunjukkan bahwaa akuntabilitas publik berpengaruh positif terhadap kinerja manajerial perangkat desa. Di mana eksistensi dari stewardship theory ialah pemberian amanah oleh masyarakat dan pemerintah diatasnya untuk mengelola sumber daya yang ada. Kemudian sumber daya tersebut dipertanggungjawabkan oleh kepala desa dan perangkat desa kepada masyarakat maupun pemerintah diatasnya. Pemerintah desa yang akuntabel akan mampu mempertanggungjawabkan segala penggunaan sumber daya yang tersedia kepada publik. Hal ini membuat perangkat desa mampu meningkatkan kinerjanya dengan cara pemuasan kebutuhan publik. Sehingga steward yang pro pemerintah desa akan termotivasi untuk memaksimalkan kinerja perangkat desa, disamping dapat memberikan kepuasan kepada kepentingan publik.

Salah satu asas pengelolaan keuangan desa ialah akuntabel. Hal ini memberikan pandangan bahwa kepala desa dan perangkat desa berkewajiban untuk mengelola sumber daya, melaporkan, dan mengungkapkan segala aktivitas dan kegiatan yang berkaitan dengan penggunaan sumber daya kepada publik. Sehingga setiap tahapan pengelolaan keuangan desa dari pertanggungjawaban, pelaksanaan, penatausahaan, pelaporan, dan pertanggungjawaban perlu adanya akuntabilitas kejujuran, akuntabilitas hukum, akuntabilitas proses, akuntabilitas program, dan akuntabilitas kebijakan. Sujarweni (2015a:29) menegaskan pentingnya akuntabilitas, karena asas ini merupakan prinsip yang menjamin bahwa setiap kegiatan yang dilakukan oleh perangkat desa dapat dipertanggungjawabkan kepada seluruh lapisan masyarakat secara terbuka.

Hal ini sejalan dengan penelitian yang dilakukan oleh Putra (2013); Saputra, et al (2014); Benawan, et al (2018) yang menunjukkan bahwa akuntabilitas publik berpengaruh terhadap kinerja. Di mana kinerja perangkat desa diukur dan dinilai melalui laporan kinerja, sehinga dalam peningkatan kinerja perangkat desa perlu adanya akuntabilitas. Adanya akuntabilitas terhadap publik mewajibkan perangkat desa mempertanggungjawabkan segala kegiatan yang dilaksanakannya dalam pengelolaan keuangan desa sehingga kinerja perangkat desa dapat di nilai oleh masyarakat maupun pemerintah desa, dengan demikian semakin baik tingkat akuntabilitas publik maka peningkatan kinerja manajerial perangkat desa semakin baik.

\section{Pengaruh Pemanfaatan Aplikasi Sistem Keuangan Desa terhadap Kinerja Manajerial Perangkat Desa}

Berdasarkan hasil pengujian hipotesis yang membuktikan bahwa pemanfaatan aplikasi sistem keuangan desa berpengaruh positif terhadap kinerja manajerial perangkat desa. Sesuai dengan adanya stewardship theory yang menuntut perangkat desa untuk mempertanggungjawabkan segala kegiatan yang dilakukannya. Untuk menciptakan pertanggungjawaban tersebut maka perangkat desa dapat memanfaatkan aplikasi sistem keuangan secara maksimal khususnya bendahara desa. Adanya aplikasi ini akan membuat bendahara desa lebih mudah dalam menatausahakan keuangan desa dan menghasilkan informasi laporan atas penerimaan dan pengeluaran keuangan desa yang akhirnya digunakan sebagai bahan pertanggungjawaban dan pengambilan keputusan, sehingga kinerja perangkat desa semakin baik.

Adanya aplikasi sistem keuangan desa yang digunakan untuk mendokumentasikan, mengadministrasikan, dan mengelola data keuangan desa dan data terkait lainnya menjadi informasi yang disajikan kepada masyarakat dan pemerintah diatasnya serta menjadi bahan pengambilan keputusan dalam rangka perencanaan, pelaksanaan, pelaporan, dan 
pertanggungjawaban pemerintah desa guna menunjang pelaporan informasi keuangan desa yang memenuhi prinsip-prinsip akurat, relevan, dan dapat dipertanggungjawabkan. Sehingga adanya aplikasi ini akan membuat bendahara desa dapat bekerja secara efektif dan efisien. Sistem ini efektif dan efisien untuk bendahara desa karena bendahara desa merasa puas dalam pengaplikasiannya, sistem mudah digunakan, biaya penerapan yang lebih kecil dibandingkan manfaat yang diperoleh dan data yang dihasilkan akan menunjang kinerja manajerial perangkat desa, sehingga pemerintah desa mampu mencapai tujuan dan mendukung pengambilan keputusan.

Hal ini selaras dengan hasil penelitian Susanti (2014); Chintya (2015) yang mana dengan adanya pemanfaatan teknologi informasi berpengaruh terhadap kinerja pemerintah daerah, hal ini karena pemanfaatan teknologi informasi yang tepat dan didukung oleh keahlian personil yang mengoperasikannya dapat meningkatkan kinerja pemerintah daerah. Hal ini juga didukung Saputri (2018) yakni pemanfaatan sistem keuangan desa berpengaruh terhadap kinerja pemerintah desa, di mana adanya aplikasi ini akan membentuk laporan keuangan yang akurat, relevan, dan dapat dipertanggungjawabkan sehingga kinerja pemerintah desa meningkat.

\section{Pengaruh Sistem Pengendalian Intern terhadap Kinerja Manajerial Perangkat Desa}

Hasil pengujian hipotesis menunjukkan bahwa sistem pengendalian intern tidak berpengaruh terhadap kinerja manajerial perangkat desa.. Hal ini menolak adanya stewardship theory yang mana kepala desa dan perangkat desa sebagai steward bekerja atas kepentingan publik sehingga mereka akan mengarahkan semua kemampuannya untuk mengefektifkan pengendalian intern, hal ini bertujuan untuk memberi keyakinan bahwa kegiatan yang dilakukan dapat berjalan sesuai dengan apa yang telah ditetapkan, sehingga dengan terciptanya pengendalian intern yang baik akan lebih mudah dalam pencapaian kinerja yang lebih baik. Hasil penelitian ini juga tidak selaras dengan penelitian terdahulu antara lain Afrida (2013); Nasir dan Ranti (2013); Putri (2013); Susanti (2104); Chintya (2015); Maharani, et al (2015); Candrakusuma dan Bambang (2017); Taradipa (2017); serta Saputri (2018) menerangkan bahwa pengendalian intern berpengaruh terhadap kinerja.

Hasil penelitian ini mendukung penelitian yang dilakukan oleh Damayanti (2017) di mana pengendalian intern tidak berpengaruh terhadap kinerja. Hasil yang serupa juga ditunjukkan oleh Mayarani, et al (2017) bahwa lingkungan pengendalian, aktivitas pengendalian, informasi dan komunikasi tidak berpengaruh terhadap kinerja. Alasan hipotesis ini ditolak karena perangkat desa hanyalah sebagai pelaksana yang bekerja sesuai dengan job desk-nya, perangkat desa bukan termasuk manajemen puncak yang bertanggungjawab terhadap kebijakan pelaksanaan pengendalian intern. Hasil penelitian ini didukung dengan adanya teori harapan yang dikemukakan oleh Vroom (1964 dalam Mayarani, et al, 2017) bahwa jika seorang perangkat desa menginginkan sesuatu dan harapan untuk memperoleh sesuatu itu cukup besar, maka perangkat desa yang bersangkutan akan sangat terdorong untuk memperoleh hal yang diinginkannya. Sehingga perangkat desa akan bekerja secara baik jika berdampak terhadap reward yang diterima.

Indikator lingkungan pengendalian, penilaian risiko, aktivitas pengendalian, informasi dan kemunikasi, serta pemantauan pengendalian sudah dilakukan secara baik sesuai dengan frekuensi jawaban responden yang menjawab kadang-kadang hingga selalu tetapi kinerja perangkat desa tidak dipengaruhi oleh hal tersebut. Faktor penyebabnya dikarenakan perangkat desa hanya akan berfokus kepada apa yang dikerjakan dan dibebankan bukan bertanggungjawab terhadap kebijakan pelaksanaan pengendalian intern. Sesuai dengan teori harapan yang dikemukakan oleh Vroom (1964 dalam Mayarani, et al, 2017) yang menjelaskan bahwa banyak sekali karyawan yag tidak termotivasi pada pekerjaan mereka dan hanya melaksanakan yang minimum sesuai dengan output yang didapatkan semata-mata untuk menyelamatkan diri atau sesuai dengan insentif yang diterima.

Alasan selanjutnya sistem pengendalian intern tidak berpengaruh terhadap kinerja manajerial perangkat desa dikarenakan minimnya sumber daya manusia. Aulia, et al. (2018) menegaskan bahwa adanya kompetensi yang dimiliki oleh pemerintah desa akan dapat meningkatkan akuntanilitas pengelolaan dana pada pemerintah desa tersebut. Kompetensi yang dimiliki oleh perangkat desa sebagai pengelola keuangan desa menjadi syarat utama agar kinerja perangkat desa menjadi baik. Dalam pengelolaan keuanga desa sebagai akibat adanya desentralisasi fiskal yang diserahkan oleh pemerintah pusat dan daerah kepada pemerintah desa dibutuhkannya 
kesiapan, salah satunya diperlukannya sumber daya manusia yang berkompeten. Hal ini diperkuat dengan hasil penelitian Meutia dan Liliana (2017) bahwa dalam hal pelaporan dan pertanggungjawaban menjadi masalah bagi beberapa desa yakni keterbatasan sumber daya manusia dan penelitian Herdianto (2018) di mana sumber daya manusia masih kurang mendukung dalam pengelolaan keuangan desa, dikarenakan masih banyak perangkat desa yang belum paham mengenai perhitungan rancangan anggaran biaya dan belum sepenuhnya. Saat ini adanya tenaga pendamping yang disediakan oleh pemerintah daerah dirasakan masih belum optimal, di mana Triani dan Susi (2018) menegaskan bahwa setiap desa didampingi oleh tenaga pendamping desa untuk membantu dalam hal pengadministrasian pengelolaan dana desa. Namun pada kenyataannya mayoritas desa mengeluhkan tenaga pendamping desa yang keberadaannya justru menjadi beban bagi desa. Tenaga pendamping desa juga tidak memiliki kemampuan dan keahlian terkait dalam hal pengelolaan dana desa.

\section{KESIMPULAN}

\section{Simpulan}

Berdasarkan hasil penelitian yang telah dilakukan maka dapat disimpulkan bahwa:

1. Partisipasi penyusunan anggaran berpengaruh positif terhadap kinerja manajerial perangkat desa. Hal ini berarti dengan adanya partisipasi perangkat desa dalam penyusunan anggaran, akan membuat perangkat desa memperoleh gambaran pemahaman yang lebih jelas tentang pekerjaan yang akan mereka kerjakan melalui anggaran desa yang telah ditetapkan dari hasil partisipasi penyusunan anggaran tersebut. Sehingga perangkat desa termotivasi untuk bertanggung jawab atas tugas yang diamanahkan kepadanya yang akhirnya dapat meningkatkan kinerja manajerial perangkat desa.

2. Akuntabilitas publik berpengaruh positif terhadap kinerja manajerial perangkat desa. Hal ini menunjukkan dengan adanya akuntabilitas terhadap publik mewajibkan perangkat desa mempertanggungjawabkan segala kegiatan yang dilaksanakannya dalam pengelolaan keuangan desa sehingga kinerja perangkat desa dapat dinilai oleh masyarakat maupun pemerintah desa, dengan demikian semakin baik tingkat akuntabilitas publik maka peningkatan kinerja manajerial perangkat desa semakin baik.

3. Pemanfaatan aplikasi sistem keuangan desa berpengaruh positif terhadap kinerja manajerial perangkat desa. Di mana dengan adanya pemanfaatan aplikasi sistem keuangan desa yang digunakan untuk mendokumentasikan, mengadministrasikan, dan mengelola data keuangan desa dan data terkait lainnya menjadi informasi yang disajikan publik guna menunjang pelaporan informasi keuangan desa yang memenuhi prinsip-prinsip akurat, relevan, dan dapat dipertanggungjawabkan. Sehingga adanya aplikasi ini akan membuat bendahara desa dapat bekerja secara efektif dan efisien, sehingga pemerintah desa mampu mencapai tujuan dan mendukung pengambilan keputusan yang akhirnya dapat meningkatkan kinerja manajerial perangkat desa

4. Sistem pengendalian intern tidak berpengaruh terhadap kinerja manajerial perangkat desa. Hal ini disebabkan karena perangkat desa hanyalah sebagai pelaksana yang bekerja sesuai dengan job desk-nya, perangkat desa bukan termasuk manajemen puncak yang bertanggungjawab terhadap kebijakan pelaksanaan pengendalian intern. Perangkat desa hanya akan berfokus kepada apa yang dikerjakan dan dibebankan bukan bertanggungjawab terhadap kebijakan pelaksanaan pengendalian intern. Selanjutnya dikarenkan minimnya sumber daya manusia yang ada pada desa tersebut.

\section{Implikasi}

Hasil penelitian ini memberikan bukti empiris bahwa partisipasi penyusunan anggaran, akuntabilitas publik, dan pemanfataan aplikasi sistem keuangan desa berpengaruh terhadap kinerja manajerial perangkat desa. Secara teori, temuan ini dapat memberikan pemahaman dan wawasan bahwa dengan adanya akuntabilitas publik, dan pemanfataan aplikasi sistem keuangan desa akan berimplikasi pada peningkatan kinerja manajerial perangkat desa yang berada di wilayah Kabupaten Sumbawa. 
Secara praktis, hasil temuan ini dapat menjadi sumber informasi terkait partisipasi penyusunan anggaran, akuntabilitas publik, dan pemanfataan aplikasi sistem keuangan desa serta sebagai bahan evaluasi yang dilakukan oleh perangkat desa dalam meningkatkan kinerja manajerial perangkat desa yang ada di wilayah Kabupaten Sumbawa. Secara kebijakan, temuan ini dapat memberikan masukan kepada pemerintah desa dan pemerintah diatasnya yang berkaitan dengan kinerja manajerial perangkat desa yang dipengaruhi oleh partisipasi penyusunan anggaran, akuntabilitas publik, dan pemanfataan aplikasi sistem keuangan desa sebagai bahan evaluasi dan melakukan fungsi monitoring dalam meningkatkan kinerja manajerial perangkat desa di wilayah Kabupaten Sumbawa.

\section{Keterbatasan}

Penelitian ini memiliki keterbatasan yang diharapkan dapat dikembangkan dan diperbaiki pada penelitian di masa yang akan datang, diantaranya:

1. Responden dalam penelitian ini hanya terbatas pada kepala desa dan ketua badan permusyawaratan desa, sementara dalam hal penunjang kinerja manajerial perangkat desa dapat dinilai oleh perangkat desa yang berada di pemerintahan desa tersebut. Sehingga peneliti selanjutnya dapat menambahkan responden seperti sekretaris desa dan kepala seksi yang berada di wilayah pemerintahan desa tersebut agar memperoleh gambaran yang jelas

Dilihat dari hasil Adjusted $R^{2}$ bahwa hanya 38,6\% variabel partisipasi penyusunan anggaran, akuntabilitas publik, pemanfaatan aplikasi sistem keuangan desa, dan sistem pengendalian intern mampu menjelaskan variabel kinerja manajerial perangkat desa. Sehingga kurang mengeksplorasi variabel-variabel lainnya yang mungkin berpengaruh. Sehingga peneliti selanjutnya dapat mengembangkan variabel-variabel lainnya yang dapat mempengaruhi kinerja manajerial perangkat desa misalnya kejelasan sasaran anggara, desentralisasi, komitmen organisasi, persepsi inovasi, budaya organisasi, dan evaluasi anggaran.

\section{DAFTAR PUSTAKA}

Afrida, N. (2013). Pengaruh Desentralisasi dan Sitem Pengendalian Intern Pemerintah terhadap Kinerja Manajarial SKPD (Studi Empiris pada Pemerintah Kota Padang). Jurnal Akuntansi Vol 1(2); 1-22.

Anton, FX. (2010). Menuju Teori Stewardship Manajemen. Majalah Ilmiah Informatika Vol 1(2); 61-80.

Aulad, A., N. Hidayati, dan Junaidi. (2018). Pengaruh Partisipasi Penyusunan Anggaran terhadap Kinerja Aparat Pemerintah Daerah: Budaya Organisasi dan Komitmen Organisasi sebagai Variabel Moderating (Studi Empiris pada SKPD Kota Malang). Jurnal Riset Akuntansi Vol. 7(7); 111-120.

Aulia, P., R. Agusti, dan Julita. (2018). Pengaruh Kompetensi Aparat Pengelola Dana Desa, Komitmen Organisasi Pemerintahan Desa, Pemanfaatan Teknologi Informasi, dan Partisipasi Masyarakat terhadap Akuntabilitas Pengelolaan Dana Desa di Kabupaten 50 Kota. Jurnal Online Mahasiswa Fakultas Ekonomi Universitas Riau Vol 1(1): 1-15.

Aprilia, R., Yuliansyah, dan Y. Agustina. (2017). Pengaruh Partisipasi Anggaran terhadap Kinerja Karyawan dengan Motovasi Kerja dan Komitmen Organisasi sebgagai Variabel Intervening (Studi Empiris pada Karyawan Perusahaan Manufaktur di Provinsi Lampung). Skripsi. Fakultas Ekonomi dan Bisnis Universitas Lampung. Bandar Lampung.

Badan Pusat Statistika Kabupaten Sumbawa. (2018). Statistika Daerah Kabupaten Sumbawa Tahun 2018.

(https://sumbawakab.bps.go.id/publication/2018/09/26/d8d6850f9bade0c14051cf83/statistikdaerah-kabupaten-sumbawa-2018.html). (Di akses 19 November 2018). 
Benawan, E.T.R., D.P.E. Saerang, dan W. Pontoh. (2018). Pengaruh Pengawasan, Akuntabilitas, dan Transparansi Keuangan terhadap Kinerja Pegawai (Studi Kasus pada Dinas Perhubungan Kota Tidore Kepulauan). Jurnal Riset Akuntansi Going Concern Vol 13(3); 72-79.

Bhakti, D.C., E. Pituringsih, dan E. Widiastuty. (2015). Pengaruh Partisipasi Penyusunan Anggaran, Kejelasan Sasaran Anggaran, dan Profesionalisme Sumber Daya Manusia terhadap Kinerja Manajerial. Jurnal Ekonomi, Manajemen, dan Akuntansi (Assets) Vol. 5(1); $29-43$.

Candrakusuma, D.A., dan B. Jatmiko. (2017). Dampak Komiten Organisasi, Sistem Pengendalian Inten Pemerintah, Akuntabilitas Publik, Partisipasi Anggaran dan Kejelasan Sasaran Anggaran terhadap Kinerja Manajerial. Jurnal Bisnis dan Ekonomi Vol 24(1); 87-93.

Chintya, I. (2015). Pengaruh Pemanfaatan Teknologi Informasi dan Sistem Pengendalian Intern Pemerintah terhadap Kinerja Instansi Pemerintah di Kota Solok (Studi pada Satuan Kerja Perangkat Daerah Kota Solok). Jurnal Akuntansi Vol. 3(1); 1-15.

Damayanti, S. (2017). Pengaruh Pengendalian Internal, Pemanfaatan Teknologi Informasi, dan Akuntabilitas Publik terhadap Kinerja Instansi Pemerintah (Studi Kasus pada Satuan Kerja Pemerintah Daerah Kabupaten Deli Serdang). Skripsi. Progran Studi Strata-S1 Departeman Akuntansi Fakultas Ekonomi dan Bisnis Universitas Sumatera Utara. Medan.

Donaldson, L. dan J.H. Davis. (1991). Stewardhip Theory or Agency Theory: CEO Governace and Shareholder Returns. Australian Journal of Management. Vol 16(1); 49-65.

Ermawati, N. (2017). Pengaruh Partisipasi Anggaran terhadap Kinerja Manajerial dengan Motivasi Kerja sebagai Variabel Pemoderasi. Jurnal Akuntansi Indonesia Vol. 6(2); 141-156.

Ghozali, I. (2016). Aplikasi Analisis Multivariete dengan Program IBM SPSS 33. Edisi Kedelapan. Badan Penerbit Universitas Diponegoro. Semarang.

Handrika, D. dan M.G. Wirakusuma. (2017). Pengaruh Partisipasi Penyusunan Anggran pada Kinerja Manajerial yang Dimoderasi Self Efficacyi dan Motivasi Kerja. Jurnal Akuntansi Vol. 20(2); 875-903.

Hendra, J. (2018). Pengaruh Partisipasi Dalam Penganggaran dan Peran Manajerial Pengelolaan Keuangan Daerah terhadap Kinerja Pemerintah Daerah (Studi Empiris pada Pemerintah Kabupaten Probolinggo). Jurnal Ilmiah Ilmu Akuntansi, Keuangan, dan Pajak Vol. 2(1); 817.

Herdianto, M.A. (2018). Mekanisme, Pelaksanaan, dan Manfaat Dana Desa Dalam Upaya Peningkatan Pembangunan Desa (Studi Kasus: Desa Bajur, Kecamatan Labu Api, Kabupaten Lombok Barat. Jurnal Ilmiah Mahasiswa Fakultas Ekonomi dan Bisnis Universitas Brawijaya $\mathrm{Vol}$ 6(2):1-15.

Heski, P., D.T. Purwanti, dan A. Fidayati. (2017). Pengaruh Partisipasi Penyusunan Anggaran, Kejelasan Sasaran Anggaran, Akuntabilitas Publik, dan Struktur Desentralisasi terhadap Kinerja Manajerial (Studi Empiris pada SKPD Kabupaten Magelang). The $6^{\text {th }}$ University Research Colloquium 2017 Universitas Muhamadiyah Magelang; 345-352.

Ibrahim, P.S. (2015). Pengaruh Anggaran Berbasis Kinerja, Transparansi, Akuntabilitas, dan Pengawasan Internal terhadap Kinerja Pegawai Sekretarial Jenderal DPR RI. Jurnal Telaah Akuntansi dan Bisnis Vol 6(1); 82-95. 
Kabarsumbawa.com. (2018). Empat Kades Bermasalah Diminta Kooperati. (https://www.kabarsumbawa.com/2018/08/13/empat-kades-bermasalah-diminta-kooperatif). (Di akses 26 September 2018).

Maharani, F.L, S.P.D Sofianti, S.M. Wardayanti. (2015). Pengaruh Pengendalian Internal terhadap Kinerja Karyawan pada Divisi Pelayanan Medis di Rumah Sakit Jember Klinik. Jurnal Akuntansi Vol. 13(2); 57-69.

Mayarani, E.I, A.D.D. Santoso, G.B. Riyandaru, dan S.M. Wardayati. (2017). Pengaruh Pengalaman Kerja dan Pengendalian Internal terhadao Kinerja Karyawan Rumah Sakit Paru Jember. Prosiding Seminar Nasional dan Call For Paper Ekonomi dan Bisnis Jember. 27-8 Oktober 2017:158-168.

Medhayanti, N.P. dan K.A. Suardana. (2015). Pengaruh Partisipasi Anggaran terhadap Kinerja Manajerial dengan Self Efficacy, Desentralisasi, dan Budaya Organisasi sebagai Variabel Pemoderasi. Jurnal Akuntansi Vol. 11(1); 155-170.

Meutia, I. dan Lilian. (2017). Pengelolaan Keuangan Dana Desa. Jurnal Akuntansi Multiparadigma Vol 8(2); 336-351.

Mulyono, S.P. (2014). Sinergitas Penyelenggaraan Pemerintahan Desa Pasca Pemberlakuan Undang-Undang Nomor 6 Tahun 2014 tentang Desa. Masalah-Masalah Hukum Vol 43(3); 438-444.

Naipospos, H., T. Taufik, dan Julita. (2015). Pengaruh Partisipasi Anggaran, Kejelasan Sasaran Anggaran dan Evaluasi Anggaran terhadap Kinerja Aparat Pemerintaha Daerah (Studi Empiris pada SKPD Kota Pekanbaru). Jurnal Online Mahasiswa Bidang Ilmu Ekonomi 2(2); $1-15$.

Nasir, A. dan R. Oktari. (2013). Pengaruh Pemanfaatan Teknologi Informasi dan Pengendalian Intern terhadap Kinerja Instansi Pemerintah (Studi Pada Kerja Perangkat Daerah Kabupaten Kampar). Jurnal Ekonomi Vol 19(2); 1-14.

Peraturan Bupati Sumbawa Nomor 12 Tahun 2015 tentang Pedoman Pengelolaan Keuangan Desa. 23 Februari 2015. Berita Daerah Kabupaten Sumbawa Tahun 2015 Nomor 12. Sumbawa

Peraturan Menteri Dalam Negeri Nomor 113 Tahun 2014 tentang Pengelolaan Keuangan Desa. 31 Desember 2017. Berita Negara Republik Indonesia Tahun 2014 Nomor 2093. Jakarta.

Peraturan Pemerintah Republik Indonesia Nomor 60 Tahun 2008 tentang Sistem Pengendalian Intern Pemerintah. 28 Agustus 2008. Lembaran Negara Republik Indonesia Tahun 2008 Nomor 127. Jakarta.

Pulausumbawanews.net. (2018). Administrasi Pemerintah Desa Di Sumbawa Masih Lemah. (http://pulausumbawanews.net/index.php/2018/04/22/administrasi-pemerintah-desa-disumbawa-masih-lemah). (Di akses 26 September 2018).

Pulausumbawanews.net. (2018). Dugaan Penyimpangan Dana Desa Mata Segera Ditindaklanjuti.(http://pulausumbawanews.net/index.php/2018/05/09/dugaan-penyimpangandana-desa-mata-segera-ditindaklanjuti). (Di akses 26 September 2018).

Pulausumbawanews.net. (2018). Kinerja Kades Di Moyo Utara Diapresiasi Kepala Dearah. (http://pulausumbawanews.net/index.php/2018/03/05/kinerja-kades-di-moyo-utaradiapresiasi-kepala-daerah/). (Di akses 26 September 2018). 
Putra, D. (2013). Pengaruh Akuntabilitas Publik dan Kejelasan Sasaran Anggaran terhadap Kinerja Manajerial Satuan Kerja Perangkat Daerah (Studi Empiris pada Satuan Kerja Perangkata Daerah Kota Padang). Jurnal Akuntansi Vol 1(1); 1-23.

Putri, G.Y. (2013). Pengaruh Komitmen Organisasi dan Sisetm Pengendalian Intern Pemerintah terhadap Kinerja Manajerial SKPD (Studi Empiris pada Satuan Kerja Perangkat Daerah Kota Padang). Jurnal Akuntansi Vol 1(1); 1-23.

Sakti, K.M.D. dan A. Taman. (2017). Pengaruh Penyusunan Anggaran Partisipatif terhadap Kinerja Manajerial dengan Komitmen Organisasi, Budaya Organisasi, dan Gaya Kepemimpinan sebagai Variabel Pemoderasi (Studi Kasus SKPD Kabupaten Sleman). Skripsi. Program Studi Akuntansi, Jurusan Pendidikan Akuntansi, Fakultas Ekonomi, Universitas Negeri Yogyakarta. Yogyakarta.

Saputra, D.S, Darwanis, dan S. Abdullah. (2014). Pengaruh Transparansi, Akuntabilitas, dan Komitmen Organisasi terhadap Kinerja Satuan Kerja Perangkat Daerah (Studi pada Pemda. Kabupaten Aceh Selatan). Jurnal Akuntansi Vol 3(2); 76-84.

Saputri, N., R.S. Pancawati, dan Nurabiah. (2018). Analisis Efektivitas Pemanfaatan Sistem Keuangan Desa (SISKEUDES) dan Pengendalian Internal terhadap Kinerja Pemerintah Desa. Skripsi. Program Studi Akuntansi Fakultas Ekonomi dan Bisnis Universitas Mataram. Mataram.

Siwi, N.D.P., A.S. Kustono, dan N. Puspitasari. (2018). Pengaruh Partisipasi Anggaran dengan Komitmen, Budaya Organisasi, dan Motivasi terhadap Kinerja Aparatur Pemerintah Kabupaten Bondowoso. Jurnal Bisnis dan Manajemen Vol. 12(1); 119-130.

Sugiyono. (2014). Metode Penelitian Bisnis. Edisi Pertama. Cetakan Kedelapan Belas. Alfabeta. Bandung.

Sujarweni, W. (2015a). Akuntansi Desa: Panduan Tata Kelola Keuangan Desa. Edisi Pertama. Pustaka Baru Press. Yogyakarta. . (2015b). Akuntansi Sektor Publik. Edisi Pertama. Pustaka Baru Press. Yogyakarta.

Susanti, I. (2014). Pengaruh Good Governance, Pemanfaataan Teknologi Informasi, dan Pengendalian Intern terhadap Kinerja Organisasi (Studi pada SKPD Kabupaten Siak). Jurnal Online Mahasiswa Ekonomi Vol 1(1); 1-14.

Taradipa, P.S. (2017). Pengaruh Pengendalian Intern terhadap Kinerja Karyawan (Studi pada PT. Bank Panin Tbk. Cabang Kendari). Jurnal Akuntansi Vol 2(1); 27-38.

Triani, N.N.A., dan S. Handayani. (2018). Praktik Pengelolaan Keuangan Dana Desa. Jurnal Akuntansi Multiparadigma Vol 9(1); 136-155.

Undang-Undang Republik Indonesia Nomor 6 Tahun 2014 tentang Desa. 15 Januari 2014. Lembaran Negara Republik Indonesaia Tahun 2014 Nomor 7. Jakarta.

Utama, E.Y. dan A. Rohman. (2013). Pengaruh Partisipasi Penyusunan Anggaran terhadap Kinerja Manajerial: Komitmen Organisasi dan Persepsi Inovasi sebagai Variabel Intervening (Studi Empiris pada Satuan Kerja Instansi Vertikal Wilayah Pembayaran Kantor Pelayanan Perbendaharaan Negara Sampit). Diponegoro Journal of Accounting Vol. 2(3); 1-12.

Yuliani, A. (2017). Festival Desa Benderang Informasi Publik, Menjadikan Pemerintah Desa Yang Terbuka. (https://kominfo.go.id/content/detail/11716/festival-desa-benderang informasipublik-menjadikan-pemerintahan-desa-yang-terbuka/0/sorotan_media). (Di akses 04 Oktober 2018). 
dan Tata Kelola Pemerintahan Desa Dlingo di Kabupaten Bantul: Pembelajaran dari Desa Percontohan”. Jurnal Akuntansi Terapan Indonesia Vol. 1 No. 1 Hal. 1-16.

Sugiyono. 2016. Metode Penelitian Kuantitatif, Kualitatif, dan R\&D. Bandung: Alfabeta.

Triani, Ni Nyoman Alit dan Susi Handayani. 2018. "Praktik Pengelolaan Keuangan Dana Desa". Jurnal Akuntansi Multiparadigma Vol. 9 No. 1 Hal.136-135.

Undang-Undang Nomor 23 Tahun 2014 tentang Pemerintahan Daerah.

Undang-Undang Nomor 6 Tahun 2014 tentang Desa.

Winaya, IK., dan IPD. Dharmanu Yudharta. 2018. "Desa Membangun: Analisis Perencanaan dan Penyusunan Anggaran Pendapatan dan Belanja Desa (APBDes) Tahun 2017 (Studi Kasus di Desa Kategori Tertinggal Pada Kecamatan Kintamani Kabupaten Bangli)”. Fakultas Ilmu Sosial dan Ilmu Politik Universitas Udayana. 